Journal Club

Editor's Note: These short, critical reviews of recent papers in the Journal, written exclusively by graduate students or postdoctoral fellows, are intended to summarize the important findings of the paper and provide additional insight and commentary. For more information on the format and purpose of the Journal Club, please see http://www.jneurosci.org/misc/ifa_features.shtml.

\title{
p38: The Link between the $\kappa$-Opioid Receptor and Dysphoria
}

\author{
Gregory V. Carr and Stephen D. Mague \\ Neuroscience Graduate Group, University of Pennsylvania, Philadelphia, Pennsylvania 19104 \\ Review of Bruchas et al. (http://www.jneurosci.org/cgi/content/full/27/43/11614)
}

Recent evidence suggests that the dynorphin- $\kappa$-opioid receptor (KOR) system is involved in the expression of a number of stress-induced behavioral changes. For example, in mice, repeated swim stress and social defeat have been shown to cause elevated forced-swiminduced immobility, increased analgesia, and potentiated cocaine place preference; these effects can be blocked by pretreatment with a KOR antagonist or deletion of the prodynorphin gene (McLaughlin et al., 2003, 2006). Further evidence that activation of the KOR by endogenous ligands is responsible for stress-induced changes in behavior is provided by data showing that systemic administration of KOR agonists induces prodepressant-like effects and, conversely, antagonism of the receptor leads to antidepressant-like effects in multiple animal models of depression (Newton et al., 2002; Mague et al., 2003; Shirayama et al., 2004).

Despite a preponderance of evidence showing that the activation of the KOR is involved in the behavioral effects of multiple stressors, the second messenger systems that mediate these effects remain unknown. In a recent issue of The Journal of Neuroscience, however, Bruchas et al. (2007) presented a convincing series of experiments that implicate $\mathrm{p} 38$, a member of the mitogen-activated protein kinase

Received Dec. 21, 2007; revised Jan. 28, 2008; accepted Jan. 29, 2008.

Correspondence should be addressed to Gregory V. Carr, Neuroscience Graduate Group, University of Pennsylvania, 1102 TRL, 125 South 31st Street, Philadelphia, PA 19104. E-mail: carrg@mail.med.upenn.edu. DOI:10.1523/JNEUROSCI.5679-07.2008

Copyright $\odot$ 2008 Society for Neuroscience $\quad$ 0270-6474/08/282299-02\$15.00/0
(MAPK) family, as an important mediator of the KOR-dependent aversive properties of stress.

The authors first set out to determine whether KOR phosphorylation, which activates the receptor, is necessary for activation (i.e., phosphorylation) of p38. They demonstrated that p38 phosphorylation was colocalized with KOR phosphorylation in cells of the nucleus accumbens, a brain region previously implicated in the behavioral effects of KOR activation after repeated swim stress (Pliakas et al., 2001; Newton et al., 2002; Shirayama et al., 2004). Phosphorylated p38 was not found in KOR-knock-out mice following the same regimen [Bruchas et al. (2007), their Fig. 1A-C (http://www. jneurosci.org/cgi/content/full/27/43/ $11614 / \mathrm{F} 1)]$, however, suggesting that KOR activation is required for the activation of p38. To quantify these findings, whole striatum extracts were assayed by Western blot. The authors showed that p38 phosphorylation was elevated by repeated swim stress in wild-type mice treated with saline, but not in KORknock-out mice, wild-type mice treated with the KOR antagonist nor-BNI (norbinaltorphimine), or wild-type animals exposed to only a single swim stress [Bruchas et al. (2007), their Fig. 2 (http:// www.jneurosci.org/cgi/content/full/27/ 43/11614/F2)]. These data provide further evidence that KOR activation is required for the stress-induced activation of p38.

The authors next performed a series of experiments to determine whether p38 activation is required for the expression of behavioral effects associated with KOR activation. The authors first injected a p38 inhibitor (SB203580 [4-(4-fluorophenyl)-2-(4-methylsulfonylphenyl)-5(4-pyridyl)-1 $H$-imidazole]) intracerebroventricularly before bouts of forced swimming. The inhibitor significantly blocked p38 phosphorylation and also reduced time spent immobile during subsequent swim tests [Bruchas et al. (2007), their Fig. 3A,B (http://www. jneurosci.org/cgi/content/full/27/43/ 11614/F3)]. This result temporally linked p38 activation to a change in behavior, increased immobility, previously associated with KOR activation.

In addition to increasing immobility in the forced swim test, KOR activation has been shown to induce conditioned place aversions, in which animals avoid environments previously associated with the administration of KOR agonists. Pharmacological inhibition of p38 completely abolished the conditioned place aversion induced by a KOR agonist without producing a preference of its own or altering preferences for cocaine-paired environments [Bruchas et al. (2007), their Fig. $4 B$ (http://www.jneurosci.org/cgi/content/ full/27/43/11614/F4)]. These data suggest that p38 inhibition specifically blocks the aversive properties of KOR activation without disrupting associative learning generally. Additionally, the authors showed that p38 inhibition did not alter taste aversion to lithium chloride [Bruchas et al. (2007), their Fig. 4C (http://www.jneurosci.org/cgi/content/ 
full/27/43/11614/F4)], an aversive learning task that is not KOR dependent.

Previous in vitro work (Bruchas et al., 2006) suggested that activation of MAPK requires recruitment of $\beta$-arrestin, a KOR-associated protein, after phosphorylation of KOR by G-protein-coupled receptor kinase 3 (GRK3). To determine whether this process is necessary for behavioral changes that occur after repeated swim stress, the authors assessed the ability of KOR agonists to induce p38 phosphorylation and increase forced-swiminduced immobility in GRK3-knock-out mice. Treatment with a KOR agonist increased p38 phosphorylation in wild-type mice, but had no effect in GRK3-knockout mice [Bruchas et al. (2007), their Fig. 5A, C (http://www.jneurosci.org/cgi/content/full/27/43/11614/F5)]. Likewise, GRK3-knock-out mice showed reduced immobility after repeated swim stress [Bruchas et al. (2007), their Fig. 5D (http://www.jneurosci.org/cgi/content/ full/27/43/11614/F5)]. GRK3 phosphorylation of p38 was shown to be specific: ERK (extracellular signal-regulated kinase), another MAPK family protein, was phosphorylated in both wild-type and GRK3-knock-out mice after KOR treatment.

In this report, Bruchas et al. (2007) connected stress-induced KOR activation to downstream activation of $\mathrm{p} 38$ and illustrated that p38 activation is required for the expression of behavioral changes previously shown to be KOR dependent. An interesting finding in the study was that the activation of p38 temporally correlated with increased immobility in the forced swim test [Bruchas et al. (2007), their Figs. 2 (http://www.jneurosci.org/ cgi/content/full/27/43/11614/F2), $3 A$ (http://www.jneurosci.org/cgi/content/ full/27/43/11614/F3)]: elevations were not present during the first swim, but rather emerged on the second day. It would be important to know, however, whether KORs are activated by the first swim, which would suggest there is a "sensitization" step required for $\mathrm{p} 38$ activation and increased immobility. This step may be the recruitment and activation of GRK3 and $\beta$-arrestin that the authors show to be required for expression of stress-induced behavioral changes. Although the authors demonstrated that the onset of behavioral changes occurred at the same time as p38 activation, it remains unclear whether concurrent elevation in p38 phosphorylation is required for the expression of stress-induced behaviors. Because p38 phosphorylation remained near peak elevation for $60 \mathrm{~min}$ and returned to baseline $6 \mathrm{~h}$ after repeated swim stress [Bruchas et al. (2007), their Fig. 2D (http://www.jneurosci.org/cgi/content/ full/27/43/11614/F2)], it would be useful to know whether increased immobility followed this same time course or whether p38 phosphorylation activates another signaling mechanism that is sufficient for the expression of increased stress-induced behaviors after dephosphorylation of $\mathrm{p} 38$.

It was previously demonstrated that repeated forced swim stress potentiates cocaine reward (McLaughlin et al., 2003). In the current paper, the authors show that blocking p38 phosphorylation does not affect cocaine reward [Bruchas et al. (2007), their Fig. $4 B$ (http://www. jneurosci.org/cgi/content/full/27/43/ $11614 / \mathrm{F} 4)]$; however, they do not test the role of p38 activation on the swim stressinduced potentiation of cocaine reward. This experiment would serve to identify another behavioral effect, previously found to be dependent on KOR activation, which is dependent on p38 activation.

With this report, Bruchas et al. (2007) have brought some insight into the role of the dynorphin-KOR system in mediating the aversive properties of stress. These findings, combined with a recent report from this group (Land et al., 2008), implicating the KOR system as a downstream target of CRF (corticotropin-releasing factor) in the regulation of stress-induced behaviors, provide much-needed mechanistic information regarding the behavioral effects of various stressors. This work provides evidence for additional sub- strates that may be manipulated to counter the maladaptive behavioral consequences of repeated stress and that could be used to treat many stressinduced disorders.

\section{References}

Bruchas MR, Macey TA, Lowe JD, Chavkin C (2006) Kappa opioid receptor activation of p38 MAPK is GRK3- and arrestin-dependent in neurons and astrocytes. J Biol Chem 281:18081-18089.

Bruchas MR, Land BB, Aita M, Xu M, Barot SK, Li S, Chavkin C (2007) Stress-induced p38 mitogen-activated protein kinase activation mediates $\kappa$-opioid-dependent dysphoria. J Neurosci 27:11614-11623.

Land BB, Bruchas MR, Lemos JC, Xu M, Melief EJ, Chavkin C (2008) The dysphoric component of stress is encoded by activation of the dynorphin $\kappa$-opioid system. J Neurosci 28:407-414.

Mague SD, Pliakas AM, Todtenkopf MS, Tomasiewicz HC, Zhang Y, Stevens Jr WC, Jones RM, Portoghese PS, Carlezon Jr WA (2003) Antidepressant-like effects of kappa-opioid receptor antagonists in the forced swim test in rats. J Pharmacol Exp Ther 305:323-330.

McLaughlin JP, Marton-Popovici M, Chavkin C (2003) $\kappa$ Opioid receptor antagonism and prodynorphin gene disruption block stressinduced behavioral responses. J Neurosci 23:5674-5683.

McLaughlin JP, Li S, Valdez J, Chavkin TA, Chavkin C (2006) Social defeat stressinduced behavioral responses are mediated by the endogenous kappa opioid system. Neuropsychopharmacology 31:1241-1248.

Newton SS, Thome J, Wallace TL, Shirayama Y, Schlesinger L, Sakai N, Chen J, Neve R, Nestler EJ, Duman RS (2002) Inhibition of cAMP response element-binding protein or dynorphin in the nucleus accumbens produces an antidepressant-like effect. J Neurosci 22:10883-10890.

Pliakas AM, Carlson RR, Neve RL, Konradi C, Nestler EJ, Carlezon Jr WA (2001) Altered responsiveness to cocaine and increased immobility in the forced swim test associated with elevated cAMP response elementbinding protein expression in nucleus accumbens. J Neurosci 21:7397-7403.

Shirayama Y, Ishida H, Iwata M, Hazama GI, Kawahara R, Duman RS (2004) Stress increases dynorphin immunoreactivity in limbic brain regions and dynorphin antagonism produces antidepressant-like effects. J Neurochem 90:1258-1268. 